\title{
STANOVENIE MIERY OSLABENIA ZÁVESU POMOCOU DYNAMICKÉHO MERANIA
}

\section{DETERMINANTION OF CABLE WEAKENING USING DYNAMIC MEASUREMENT}

\author{
Kristína Bezručová*, ${ }^{*}$, Radim Nečas ${ }^{1}$
}

*bezrucova.k@fce.vutbr.cz

${ }^{1}$ Vysoké učení technické v Brně, Fakulta stavební, Ústav betonových a zděných konstrukcí, Veveří 331/95, 602 00 Brno, Česká Republika

\begin{abstract}
Abstrakt
Článok pojednáva o možnostiach merania dynamickej odozvy závesov na budenie impulzom. Uvedené sú základné vzt’ahy medzi silou v lane a vlastnou frekvenciou kmitania závesu a podmienky použitia týchto vzt’ahov na skutočnej konštrukcii.

Poznatky sú následne aplikované na lávke pre chodcov v meste Napajedla. Ciel'om merania bolo stanovenie vel'kosti sily v závesoch, zhodnotenie ich stavu a namáhania na základe dynamickej odozvy.
\end{abstract}

\section{Klíčová slova}

Kmitanie strún, vlastné frekvencie, sila v závese, oslabenie prierezu, lávka pre peších

\section{Abstract}

Paper discusses the possibilities of measuring the dynamic response of cables to impulse excitation. Basic relations between cable force and natural frequency of cable and conditions of use on real structures are mentioned.

Methods are applied on a pedestrian bridge in Napajedla. The aim of the measurement was to determine the cable force and to evaluate their condition and stress based on the dynamic response.

\section{Key words}

String oscilation, natural frequencies, cable force, cross - sectional weakening, pedestrian bridge

\section{1 ÚVOD}

Diagnostika mostných objektov za účelom stanovenia ich skutočného stavu, možných porúch a rozdelenia napätosti v konštrukcii je disciplína potrebná $\mathrm{k}$ zabezpečeniu ich bezpečného fungovania a cesta $\mathrm{k}$ predíženiu ich životnosti.

Jednou z možných nedeštruktívnych metód pre zhodnotenie stavu konštrukcie je meranie jej dynamickej odozvy a následné stanovenie modálnych parametrov. Pretože modálne parametre konštrukcie nesú informáciu o jej napätosti, rozložení hmoty a okrajových podmienkach, zmena v statickom pôsobení konštrukcie sa prejaví v zmene modálnych parametrov.

Na diagnostiku závesov je možné použit' metódu využívajúcu vzt’ah medzi vlastnou frekvenciou predopnutej struny, prierezovými a materiálovými charakteristikami a predpínacou silou.

Zhodnotenie stavu závesu tak spočíva v ich vybudení, zaznamenaní odozvy, vyhodnotení vlastných frekvencií závesu a následnej analýze ich stavu na základe známych vzt’ahov.

Táto metóda zameraná na stanovenie síl v závesoch a odhad miery ich oslabenia bola použitá na lávke pre chodcov v meste Napajedla. 


\section{TEÓRIA KMITANIA ZÁVESOV}

\section{Vzt’ahy pre výpočet sily v závese}

Modálne parametre - vlastné tvary a frekvencie podávajú u konštrukcií ako celku informáciu o jej stave, ako je rozloženie hmoty a spôsob podoprenia. Podobne, dynamická odozva závesov nesie informáciu o ich parametroch - dížke, hmotnosti, priereze a napätosti.

Medzi vlastnou frekvenciou kmitania závesu, silou v ňom a jeho d’alšími charakteristikami tak existuje priama závislost'. Pre stanovenie vzt’ahu medzi jednotlivými veličinami sa používajú rôzne zjednodušenia a predpoklady [1],[2] ktoré vedú na niekol'ko jednoduchých vzorcov pre určité typy idealizácie závesu [3].

Základnými spôsobmi idealizácie sú lano (bez ohybovej tuhosti) alebo nosník (s ohybovou tuhost’ou), s uvážením tlmenia alebo bez. Nosník sa uvažuje podoprený obojstranne kíbovo alebo s votknutím.

Vzt’ah pre výpočet predpínacej sily v netlmenej strune:

$$
F=\frac{4 f_{n}^{2} \mu l^{2}}{n^{2}}
$$

Vzt’ah pre výpočet predpínacej sily v tlmenej strune:

$$
F=\frac{4 f_{n t}^{2} \mu l^{2}}{n^{2}} \cdot \frac{1}{1-\zeta^{2}}
$$

Vzt’ah pre výpočet predpínacej sily v netlmenom obojstranne kíbovo uloženom nosníku:

$$
F=\frac{4 l^{2} \rho A}{n^{2}} \cdot\left(f_{n}^{2}-\frac{n^{4} \pi^{2} E I}{4 l^{4} \rho A}\right)
$$

Vzt’ah pre výpočet predpínacej sily v netlmenom obojstranne votknutom nosníku:

$$
\begin{gathered}
F=\frac{\left(\sqrt{\left|t^{2}-4 y z\right|} \pm t\right)^{2}}{4 y^{2}} \\
t=f_{n}-\frac{n}{l^{2}} \cdot \sqrt{\frac{E I}{\rho A^{\prime}}} \\
y=\frac{n}{2 l \sqrt{\rho A}} \\
z=\frac{n}{2 l \sqrt{\rho A}}\left(4+\frac{n^{2} \pi^{2}}{2}\right) \frac{E I}{l^{2}}
\end{gathered}
$$

kde $F[\mathrm{~N}]$ značí predpínaciu silu, $f_{n}[\mathrm{~Hz}] n$-tú vlastnú frekvenciu priečneho kmitania závesu, $n$ [-]poradové číslo vlastnej frekvencie, $l[\mathrm{~m}]$ kmitajúcu dížku závesu, $A\left[\mathrm{~m}^{2}\right]$ prierezovú plochu závesu, $I\left[\mathrm{~m}^{4}\right]$ moment zotrvačnosti závesu, $\rho\left[\mathrm{kg} / \mathrm{m}^{3}\right]$ objemovú hmotnost' závesu, $E[\mathrm{~Pa}]$ modul pružnosti závesu, $\mu=\rho \cdot A$ hmotnost' závesu na meter dížky, $\zeta[-]$ pomerný útlm.

\section{Použitie na skutočných konštrukciách}

Uvedené vzt'ahy (1), (2), (3), (4) je možné pre výpočet predpínacej sily v závese použit' v prípade, že sú známe všetky ostatné parametre - charakteristiky priečneho rezu, kmitajúca dížka závesu, jeho hmotnost' a tlmenie.

Na skutočných konštrukciách však môže v dôsledku dlhodobých javov (dotvarovanie, zmrašt'ovanie, relaxácia) dôjst' k prerozdeleniu síl v závesoch, prípadne k poškodeniu závesu a oslabeniu jeho priečneho rezu, napríklad koróziou. Pokial' niektoré z uvedených parametrov nie sú známe, predpínaciu silu nie je možné bez d'alších predpokladov stanovit'.

Z hl'adiska diagnostiky však samotná znalost' hodnoty vlastnej frekvencie, pri zavedení pomocných predpokladov podáva informáciu o stave závesu na jestvujúcej konštrukcii.

Predpokladmi pre d’alší výpočet je odhadnutie stavu závesov. Z krátkodobého hl'adiska existuje niekol'ko možností: 
- $\quad$ prierezové charakteristiky závesov sú známe a vyčíslitel’né (závesy sú bez poškodenia priečneho rezu, prípadne je známa miera ich poškodenia);

- prierezové charakteristiky závesov nie sú známe.

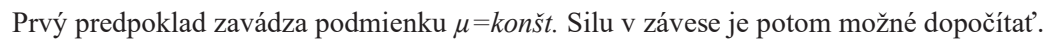

Za predpokladu neznámych prierezových charakteristík je na konštrukciách s viacerými závesmi rovnakej dížky a s rovnakou mernou hmotnost'ou $\mu$ možné vzájomným porovnaním vlastných frekvencií jednotlivých závesov stanovit’ rozdelenie síl v nich.

V špeciálnom prípade, kedy sila v závese je známa (pri poškodení závesu dochádza iba k zmene napätia v materiáli závesu, nie k redistribúcii síl), je zo známej sily $F$ a zmeranej vlastnej frekvencie možné stanovit' prierezové charakteristiky.

Na skutočnej konštrukcii nejde použit' oba predpoklady zároveň. Znamenalo by to, že vyššia frekvencia označuje bud' nepoškodený záves z hl'adiska priečneho rezu s vyššou predpínacou silou, alebo záves s istou mierou poškodenia a neznámou silou v ňom.

Pri súčasnej neznalosti miery poškodenia závesu a sily v ňom, je dynamické meranie vlastných frekvencií možné použit' pre sledovanie zmien z dlhodobého hl'adiska. Opät' existujú dve možnosti:

- $\quad$ prierezové charakteristiky závesov sa v čase nemenia (nedochádza k degradácii priečneho rezu),

- $\quad$ sila v závese sa v čase nemení, môžu sa menit’ prierezové charakteristiky.

V prípade konštantných prierezových charakteristík ( $\mu=k o n s ̌ t$.$) je možné zmenou vlastnej frekvencie stanovit’$ zmenu silového namáhania - zmena sily je daná pomerom kvadrátu vlastných frekvencií.

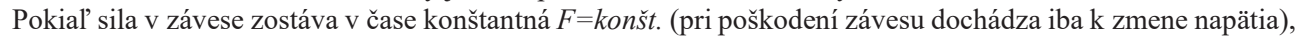
poškodením priečneho rezu sa zmenší hodnota mernej hmotnosti $\mu$. Z uvedených vzt'ahov je vidiet', že tým nutne stúpne vlastná frekvencia závesu. Zmena vlastnej frekvencie tak indikuje zmenu poškodenia. Mieru zmeny poškodenia je rovnako možné stanovit’ z pomeru kvadrátu vlastných frekvencií.

\section{DYNAMICKÉ MERANIE NA LÁVKE V NAPAJEDLÍCH}

Dynamické meranie závesov za účelom stanovenia silového namáhania a zhodnotenia miery poškodenia závesov bolo použité na zavesenej lávke pre chodcov cez rieku Moravu v meste Napajedla (Obr. 1).

\section{Popis konštrukcie}

Meraná konštrukcia je zavesená lávka pre chodcov s troma pol’ami s rozpätím 16,965 m - 35,970 m - 16,705 m.

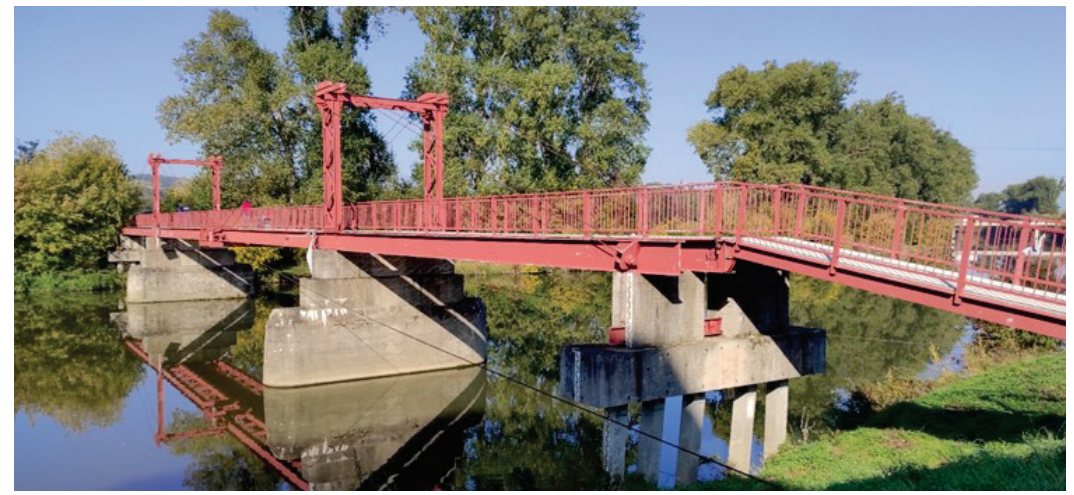

Obr. 1 Meraná konštrukcia - lávka cez Moravu v Napajedlech.

Hlavnú nosnú konštrukciu meranej lávky tvorí štvorica hlavných ocel'ových nosníkov a 16 nosných lán s priemerom $25 \mathrm{~mm}$ (lano 35,5 ČSN 02 4313.31). Lano je tvorené jednotlivými drôtmi $1+6+12+18$ s priemerom 3,75 mm (duša) a 3,55 mm (drôty vo vrstvách). Laná sú kotvené v ocel'ových prípravkoch na krajných hlavných nosníkoch. Cez pylóny tvorené priehradovou konštrukciou výšky 4,85 m sú vedené cez ocel'ové sedlá. 
Hlavné nosníky sú vzájomne spojené a stužené priečnikmi, ktoré roznášajú zat’aženie zo stredných hlavných nosníkov do krajných hlavných nosníkov a vytvárajú rošt. Uprostred stredného pol’a lávky sú dva priečniky prenášajúce zat’aženie $\mathrm{z}$ hlavných nosníkov do zavesených lán.

Za účelom stanovenia stavu lán a miery ich oslabenia bola prevedená nedeštruktívna kontrola ocel'ových lán spoločnost'ou INWIRO [4]. Kontrolou lán bol konštatovaný maximálny korozívny úbytok na vol’ných úsekoch lán do $15 \%$, bez špecifikácie percenta korózie v jednotlivých lanách. Správa bližšie špecifikuje koróziu v mieste koncoviek (minimálne korozívne úbytky 10-40 \%) a pylónov (vizuálne neboli zistené korozívne úbytky).

\section{Meranie}

Kmitanie závesov bolo zaznamenávané (Obr. 2) po dobu 150 s so vzorkovacou frekvenciou $1200 \mathrm{~Hz}$ snímačom zrýchlenia - akcelerometer B1, SEIKA Mikrosystemtechnik GmbH. Snímač bol umiestnený na závese v priečnom horizontálnom smere $\mathrm{v}$ mieste nenulovej výchylky niektorého z prvých vlastných tvarov závesu, $4 \mathrm{~m}$ od kotvy závesu na hlavnom nosníku. Snímač bol na záves uchytený pomocou ocel'ovej svorky s rovnou plochou na umiestnenie snímača.

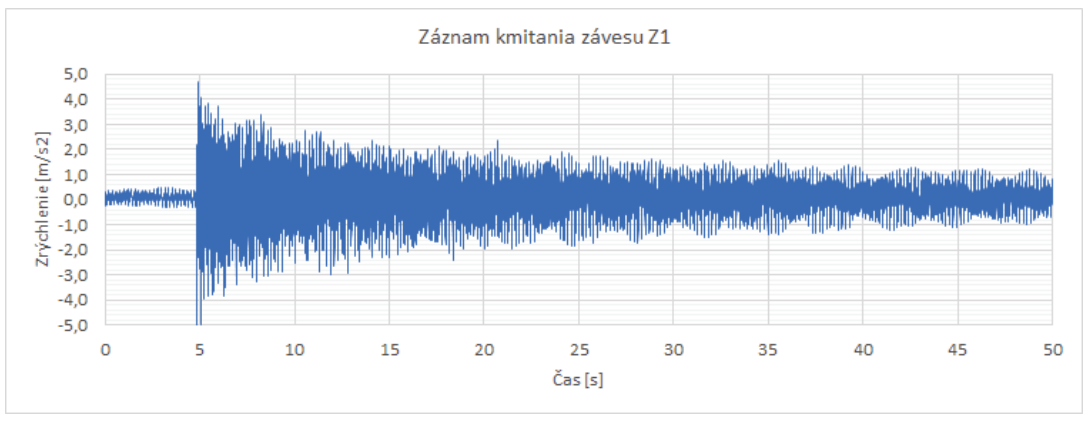

Obr. 2 Časový záznam kmitania závesu Z1.

Závesy boli pre účely merania číslované podl’a schémy na Obr. 3.

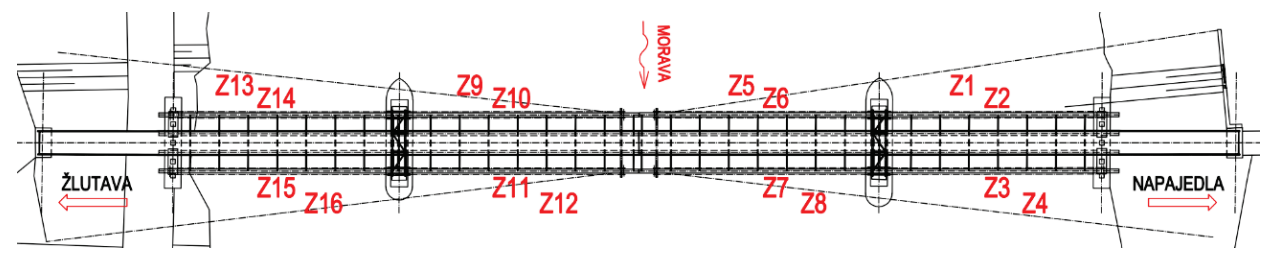

Obr. 3 Označenie závesov.

\section{VÝSLEDKY}

Záznamy kmitania sú podrobené frekvenčnej analýze v softvéri Nextview 4.

Parametre závesov sú uvažované nasledovne: modul pružnosti $E=150 \mathrm{GPa}$ [7], menovitá hmotnost' lana $\mu=2,88 \mathrm{~kg} / \mathrm{m}$, prierezová plocha lana $A_{100}=367,3 \mathrm{~mm}^{2}$ a moment zotrvačnosti prierezu závesu $I_{100}=14059,15 \mathrm{~mm}^{4}$. Uvedené charakteristiky zodpovedajú neporušenému lanu bez poškodenia koróziou.

Oslabenie závesov koróziou je uvažované jednotne v hodnote $15 \%$, náhradný prierez lana je stanovený ako $A_{85}=0,85 \cdot 367,3 \mathrm{~mm}^{2}$ a moment zotrvačnosti ako $I_{85}=0,85 \cdot 14059,15 \mathrm{~mm}^{4}$.

Hmotnost' lana bola stanovená za predpokladu objemovej tiaže oceli $\rho=7850 \mathrm{~kg} / \mathrm{m}^{3}$.Vol'ná kmitajúca dížka $l=17 \mathrm{~m}$ bola stanovená ako dĺžka lana medzi kotevným prípravkom a počiatkom ocel’ového sedla pylónu.

Vo výpočtoch sú vzhl'adom k nízkym hodnotám pomerného útlmu použité vzt’ahy pre netlmené kmitanie. 


\section{Stanovené vlastné frekvencie}

Frekvenčná analýza kmitania závesov je prevedené metódou rýchlej Fourierovej transformcácie [5] s priemerovaním za použitia Hanningovho časového okna [6]. Rozlišovací krok frekvencie je $\Delta \mathrm{f}=0,02034505 \mathrm{~Hz}$.

Vlastné frekvencie závesov sú určené ako vrcholy vo frekvenčnom spektre (Obr. 4)

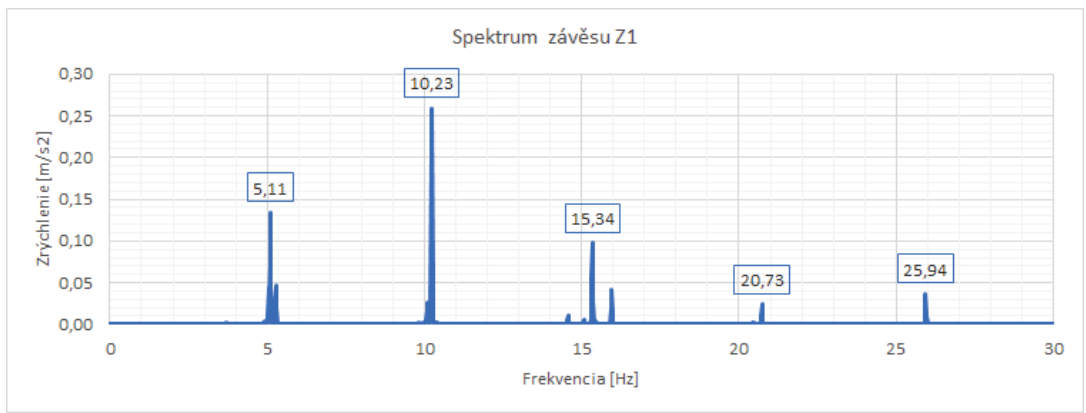

Obr. 4 Frekvenčné spektrum závesu Z1.

Vlastné frekvencie sú uvedené v Tab. 1. Maximálna prvá vlastná frekvencia je 5,107 Hz, minimálna 4,537 Hz.

Tab. 1 Prvé vlastné frekvencie závesov lávky pre chodcov v Napajedlách.

\begin{tabular}{cccccccc}
\hline Záves & $\begin{array}{c}\text { Frek. } \\
{[\mathbf{H z}]}\end{array}$ & Záves & $\begin{array}{c}\text { Frek. } \\
{[\mathbf{H z}]}\end{array}$ & Záves & $\begin{array}{c}\text { Frek. } \\
{[\mathbf{H z}]}\end{array}$ & Záves & $\begin{array}{c}\text { Frek. } \\
{[\mathbf{H z}]}\end{array}$ \\
\hline Z1 & 5,107 & $\mathrm{Z} 5$ & 5,086 & $\mathrm{Z} 9$ & 4,537 & $\mathrm{Z} 13$ & 4,557 \\
Z2 & 5,046 & $\mathrm{Z} 6$ & 5,086 & $\mathrm{Z} 10$ & 4,781 & $\mathrm{Z} 14$ & 4,557 \\
Z3 & 5,005 & $\mathrm{Z} 7$ & 4,985 & $\mathrm{Z} 11$ & 5,005 & $\mathrm{Z} 15$ & 4,871 \\
Z4 & 4,924 & $\mathrm{Z} 8$ & 4,883 & $\mathrm{Z} 12$ & 4,618 & $\mathrm{Z} 16$ & 4,598 \\
\hline
\end{tabular}

\section{Výpočet síl v závesoch}

Sily v závesoch (Tab. 2) sú stanovené z prvých vlastných frekvencií priečneho kmitania závesov za predpokladu, že záves nie je nijak poškodený $\left(F_{100}\right.$, parametre $\left.A_{100,}, I_{100}\right)$, prípadne, že je oslabený o $15 \%\left(F_{85}\right.$, parametre $A_{85}$, $I_{85}$ ), vid' [4]. Pre výpočet je použitý vzt’ah pre netlmený obojstranne votknutý nosník (4).

Tab. 2 Vypočítané sily v závesoch.

\begin{tabular}{cccccccccccc}
\hline Záves & $\begin{array}{c}\mathbf{F}_{100} \\
{[\mathbf{k N}]}\end{array}$ & $\begin{array}{c}\mathbf{F}_{\mathbf{8 5}} \\
{[\mathbf{k N}]}\end{array}$ & Záves & $\begin{array}{c}\mathbf{F}_{\mathbf{1 0 0}} \\
{[\mathbf{k N}]}\end{array}$ & $\begin{array}{c}\mathbf{F}_{\mathbf{8 5}} \\
{[\mathbf{k N}]}\end{array}$ & Záves & $\begin{array}{c}\mathbf{F}_{\mathbf{1 0 0}} \\
{[\mathbf{k N}]}\end{array}$ & $\begin{array}{c}\mathbf{F}_{\mathbf{8 5}} \\
{[\mathbf{k N}]}\end{array}$ & Záves & $\begin{array}{c}\mathbf{F}_{\mathbf{1 0 0}} \\
{[\mathbf{k N}]}\end{array}$ & $\begin{array}{c}\mathbf{F}_{85} \\
{[\mathbf{k N}]}\end{array}$ \\
\hline Z1 & 83,6 & 71,1 & $\mathrm{Z} 5$ & 82,9 & 70,5 & $\mathrm{Z} 9$ & 65,7 & 55,8 & $\mathrm{Z} 13$ & 66,3 & 56,3 \\
Z2 & 81,6 & 69,4 & $\mathrm{Z} 6$ & 82,9 & 70,5 & $\mathrm{Z} 10$ & 73,1 & 62,1 & $\mathrm{Z} 14$ & 66,3 & 56,3 \\
Z3 & 80,3 & 68,2 & $\mathrm{Z} 7$ & 79,6 & 67,7 & $\mathrm{Z} 11$ & 80,3 & 68,2 & $\mathrm{Z} 15$ & 73,1 & 62,1 \\
Z4 & 77,6 & 66,0 & $\mathrm{Z} 8$ & 76,3 & 64,9 & $\mathrm{Z} 12$ & 68,1 & 57,9 & $\mathrm{Z} 16$ & 67,5 & 57,4 \\
\hline
\end{tabular}

Maximálna sila pre plný prierez závesu je 83,6 kN (záves Z1), minimálna 65,7kN (záves Z9).

Maximálna sila pre prierez závesu oslabený o 15 \% je 71,1kN (záves Z1), minimálna 55,8kN (záves Z9).

\section{Stanovenie oslabenej plochy prierezu}

Vzhl’adom ku geometrii konštrukcie (rovnaká dĺžka a uhol použitých závesov, spôsob ukotvenia v hlavných nosníkoch a uloženie na pylóny, symetria okolo pozdížnej osi) sú závesy v ideálnom prípade namáhané rovnakou silou. Je teda možné zaviest' predpoklad o konštantnej sile $F_{s}$ v závesoch a stanovit' mieru oslabenia priečneho rezu.

Výpočet oslabenej plochy $A_{\text {osl }}$ prierezu (Tab. 3) bol prevedený za predpokladu sily $F_{s}=68,6 \mathrm{kN}$ rovnej minimálnej sile v lane stanovenej zo vzt’ahu pre netlmenú strunu (1) pre záves s minimálnou frekvenciou - Z09. 
Tab. 3 Vypočítaná oslabená plocha prierezu závesu.

\begin{tabular}{|c|c|c|c|c|c|c|c|c|c|c|c|}
\hline Záves & $\begin{array}{c}\mathbf{A}_{\text {osl }} \\
{\left[\mathbf{m m}^{2}\right]}\end{array}$ & $\begin{array}{c}\Delta \mathbf{A} \\
{[\%]}\end{array}$ & Záves & $\begin{array}{c}\mathbf{A}_{\mathrm{osl}} \\
{\left[\mathrm{mm}^{2}\right]}\end{array}$ & $\begin{array}{c}\Delta \mathbf{A} \\
{[\%]}\end{array}$ & Záves & $\begin{array}{c}\mathbf{A}_{\mathrm{osl}} \\
{\left[\mathrm{mm}^{2}\right]}\end{array}$ & $\begin{array}{c}\Delta \mathbf{A} \\
{[\%]}\end{array}$ & Záves & $\begin{array}{c}\mathbf{A}_{\text {osl }} \\
{\left[\mathrm{mm}^{2}\right]}\end{array}$ & $\begin{array}{c}\Delta \mathbf{A} \\
{[\%]}\end{array}$ \\
\hline Z1 & 289,9 & 21,1 & $\mathrm{Z5}$ & 292,3 & 20,4 & Z9 & 367,3 & 0,0 & Z13 & 364,1 & 0,9 \\
\hline $\mathbf{Z 2}$ & 296,9 & 19,2 & Z6 & 292,3 & 20,4 & Z10 & 330,8 & 9,9 & Z14 & 364,1 & 0,9 \\
\hline Z3 & 301,8 & 17,8 & $\mathrm{Z7}$ & 304,2 & 17,2 & Z11 & 301,8 & 17,8 & Z15 & 330,8 & 9,9 \\
\hline Z4 & 311,8 & 15,1 & Z8 & 317,1 & 13,7 & Z12 & 354,5 & 3,5 & Z16 & 357,6 & 2,6 \\
\hline
\end{tabular}

\section{Zhodnotenie výsledkov}

Z tabul'ky vlastných frekvencií (Tab. 1) je viditel’ný rozdiel medzí maximálnou a minimálnou prvou vlastnou frekvenciou v hodnote $0,57 \mathrm{~Hz}$, čo zodpovedá $11,16 \%$.

Tento rozdiel vlastných frekvencií sa prejaví rozdielom maximálnej a minimálnej sily až o 21,5% (pri výpočte s uvážením korózie aj bez).

Celkovo sa možná hodnota síl v závesoch pohybuje medzi 55,8 kN (minimum s uvážením korózie) a 83,6 kN (maximum bez korózie). Vzhl'adom k minimálnej sile je rozdiel síl takmer $50 \%$.

Minimálna náhradná plocha prierezu závesu, vychádza (viz 2) v závese s maximálnou frekvenciou (Z1). Maximálny rozdiel medzi nepoškodenou a oslabenou plochou prierezu je $21,1 \%$. Pre záves s minimálnou frekvenciou (Z9) je náhradná plocha prierezu totožná s nepoškodenou, tento výsledok vychádza zo zavedeného predpokladu pre výpočet $A_{\text {osl }}$.

Na základe správy spoločnosti INWIRO [4], prevedených výpočtov a analýzy optimálneho statického pôsobenia konštrukcie, je možné predpokladat', že zmena vlastných frekvencií skôr indikuje oslabenie priečneho rezu, než redistribúciu síl v závesoch. Odhad oslabenej plochy prierezu do $21 \%$ korešponduje s odhadnutou koróziou lán (15\% na vol’ných úsekoch). Korózia v mieste koncoviek napomáha vytvoreniu kíbového uloženia. To je pri výpočte oslabenia uvažované implicitne vzhl'adom k použitiu vzt’ahu pre netlmenú strunu.

Správna interpretácia výsledkov je nutná v prípade zistenia kritickej hodnoty korózie jednotlivých lán a potrebe ich výmeny. Na základe stanovených odhadov oslabenej plochy prierezu je možné stanovit' poradie výmeny závesov. Aby nedošlo k pret’aženiu najviac oslabených závesov pri výmene, poradie výmeny by bolo dané hodnotou vlastnej frekvencie od najvyššej k najnižšej.

\section{ZÁVER}

Z experimentálneho stanovenia síl a oslabenej plochy prierezu závesov je možné stanovit’ niekol'ko záverov.

Pomocou vzt'ahov medzi vlastnou frekvenciou závesu, prierezovými a materiálovými charakteristikami a silou v závese je možné stanovit' hodnotu predpínacej sily aj odhadnút' oslabenie priečneho rezu. Pre stanovenie oboch veličín je potreba zavedenia doplňujúcich predpokladov o stave kontrolovaných závesov.

Nesprávne zavedenie predpokladov a použitie vzt'ahov medzi jednotlivými veličinami môže viest' k paradoxným záverom. Výpočet sily v závese alebo prípadne oslabenie prierezovej plochy závesu je preto potreba uvažovat' s ohl'adom na predpokladané správanie a namáhanie konštrukcie v čase diagnostického prieskumu.

\section{Pod'akovanie}

Teoretické podklady pre prezentované výsledky boli získané za finančnej podpory z prostriedkov štátneho rozpočtu prostredníctvom TA ČR v rámci projektu CK01000042 „Upřesnění zbytkové únosnosti předpjatých mostü“.

\section{Použité zdroje}

[1] BREPTA, Rudolf, František TUREK a Ladislav PU゚ST. Mechanické kmitání. Praha: Sobotáles, 1994. Česká matice technická (Sobotáles). ISBN 80-901-6848-5.Citace 2

[2] GEIER, Roman, Guido DE ROECK a Johannes PETZ. Cable Force Determination for the Danube Channel Bridge in Vienna. Structural Engineering International. 03/2005n. 1.

[3] NEČAS, Michael. Meření napětí v táhlech pomocí vlastních frekvencí. Praha, 2010. Bakalářská práce. České vysoké učení technické v Praze.

[4] Inspekční zpráva č. 044-2021, Nedestruktivní kontrola ocelových lan, INWIRO s.r.o., 26.4.2021

[5] SMITH, Steven W. The Scientist and Engineer's Guide to Digital Signal Processing [online]. [cit. 2021- 
12-5]. Dostupné z: http://www.dspguide.com/pdfbook.htm

[6] BILOŠOVÁ, Alena. Aplikovaný mechanik jako součást týmů konstruktérů a vývojářů [online]. Ostrava: Vysoká škola báňská - Technická univerzita Ostrava, Fakulta strojní, 2012 [cit. 2019-08-28]. ISBN 978-80-248-2758-2. Dostupné z: $\quad$ http://projekty.fs.vsb.cz/147/ucebniopory/978-80-248-27582.pdf

[7] Prof. Ing. Stanislav Kmet', CSc. Novodobé lanové a membránové konstrukce, časopis Stavitelství, https://www.asb-portal.cz/stavebnictvi/novodobe-lanove-a-membranove-konstrukce 